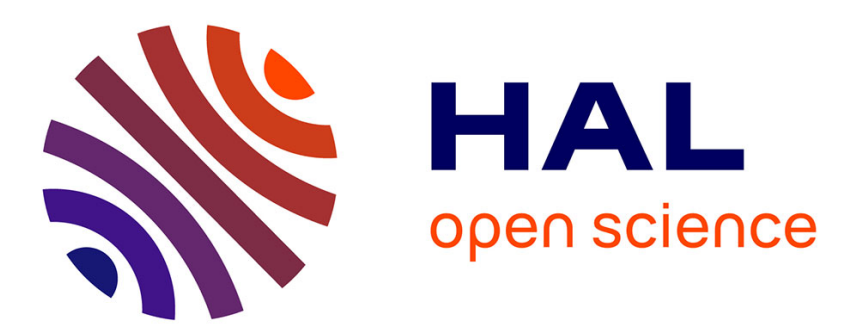

\title{
Assessing the Structural and Psychometric Properties of a New Personality Measure for Use With Military Personnel in the French Armed Forces
}

\author{
Anne Congard, Pascal Antoine, Pierre-Yves Gilles
}

\section{- To cite this version:}

Anne Congard, Pascal Antoine, Pierre-Yves Gilles. Assessing the Structural and Psychometric Properties of a New Personality Measure for Use With Military Personnel in the French Armed Forces. Military Psychology, 2012, 24 (3), pp.289 - 311. 10.1080/08995605.2012.678242 . hal-01772296

\author{
HAL Id: hal-01772296 \\ https://hal.science/hal-01772296
}

Submitted on 1 May 2018

HAL is a multi-disciplinary open access archive for the deposit and dissemination of scientific research documents, whether they are published or not. The documents may come from teaching and research institutions in France or abroad, or from public or private research centers.
L'archive ouverte pluridisciplinaire HAL, est destinée au dépôt et à la diffusion de documents scientifiques de niveau recherche, publiés ou non, émanant des établissements d'enseignement et de recherche français ou étrangers, des laboratoires publics ou privés. 
Running Head: STRUCTURAL \& PSYCHOMETRIC PROPERTIES OF TAMI P

Assessing the Structural and Psychometric Properties of a New Personality Measure for Use with Military Personnel in the French Armed Forces

Anne Congard, Pascal Antoine and Pierre-Yves Gilles

\section{Author Note}

Anne Congard, Department of studies and research in applied psychology, Psychology Navy Service, CIN St Mandrier, French Navy.

Pascal Antoine, Lille Nord University, URECA center, F-59653.

Pierre-Yves Gilles, Provence University - Aix-Marseille I, PsyCLÉ center, EA 3273.

Address correspondence to Anne Congard, Section d'études et de recherches des applications de la psychologie, CIN St Mandrier, BP505, 83800 TOULON CEDEX 9. Email :

anne.congard@laposte.net 


\begin{abstract}
We evaluated the measurement properties of a new personality scale for use with military personnel in the French Navy $(\mathrm{N}=1,266)$. Principal components analyses indicated that a five-factor hierarchical structure assessing emotional stability, ascendancy, openness, agreeableness and conscientiousness described the underlying pattern of correlations among items. Each factor was comprised of two facets that included 7 items per facet for a total of 70 items. Reliability analyses indicate that the factors and corresponding facets were internally consistent and temporally stable. Validity analyses indicate that the TAMI-P was significantly correlated with comparable measures of personality - correlations ranged from .53 to .68 with the Revised NEO Personality Inventory and the Big Five Questionaire. We discuss the theoretical, methodological, and practical implications of our findings for future research.
\end{abstract}

Keywords: personality, five-factor model, factorial approach, selection assessment, career guidance. 
Assessing the Structural and Psychometric Properties of a New Personality Measure for Use with Military Personnel in the French Armed Forces

Since the beginning of the last century, there have been numerous studies of personality and the best way of assessing it. The lexical hypothesis has tended to predominate, especially in the field of assessment psychology applied to work, the aim being to produce a descriptive model of personality containing short and accurate definitions. The five-factor model (FFM) has served as a benchmark for describing personality structure for almost two decades (McCrae \& John, 1992). It has become the model of choice for companies keen to use personality tests for recruiting staff. Offering an attractive compromise between exhaustiveness and parsimony, it provides a simple and easily understandable model of personality, with clear structural relations between the different facets (Goldberg, 1993; John \& Srivastava, 1999). There has recently been a great deal of debate about the hierarchical structure of this type of model and we have recently witnessed the advent of a higher-order structure featuring two metatraits (Ashton et al, 2004; DeYoung, 2006; McCrae et al., 2008) or even a general factor of personality (Rushton, Irwing \& Booth, 2010). For their part, DeYoung, Quilty, and Peterson (2007) have shown that there is also an intermediate level between the Big Five domains and their corresponding facets, which can be clustered around 10 Mid-Level Aspects. FFM and DeYoung et al. (2007) researches have inspired the structure of our French Military Admission Test - Personality (in french TAMI$\mathrm{P})$.

The predictive validity of the BIG FIVE is now well established, as far as job performance is concerned (Schmidt \& Ones, 1992; Barrick \& Mount, 1991). According to Hogan (1996), the combined use of a personality questionnaire, job analysis (job profile, company profile, corporate culture, etc.) and information yielded by aptitude tests is highly predictive of job success $\left(R^{2}=.60\right.$ or even .70$)$. This predictive validity has been tested not 
only in terms of performance in the workplace (Mount \& Barrick, 1998) but also in terms of motivation, using indicators relating to career development (Judge \& Higgins, 1999). Each of the five factors predicts particular aspects of career success.

The popularity of the FFM, its intrinsic qualities and its ability to predict job performance prompted us to develop a variant of the BIG FIVE for the purpose of recruiting sailors and subsequently providing them with mid-career guidance. To obtain a structure with a small number of items, we made a theorical choice between the conctructs of the FFM in order to select the most useful ones for military recruitment.

Theoretical Framework of Factors and Facets of Personality in Military Populations

Neuroticism (N) vs. Emotional stability (SE), Extraversion (E), Openness (O), Agreeableness (A) and Conscientiousness (C) are the most common labels given to the BIG FIVE dimensions, although they can vary from one instrument to another, depending on the dimension's theoretical content. For example, E stands for energy in the Big Five Questionnaire (BFQ; Caprara, Barbaranelli, Borgogni, \& Perugini, 1993) but extraversion in the Revised NEO Personality Inventory (NEO PI-R; Costa \& McCrae, 1992). Taking the BIG FIVE constructs as our starting point, our aim was to identify the requisite qualities for careers within the French Navy in order to define the most relevant traits for the purposes of military recruitment and slot them into a 10-facet structure (see Table 1). The section below reviews extant research and theory to explicate the conceptual framework guiding our study.

Neuroticism vs. Emotional Stability. One of the first dimensions to have been isolated by researchers, is now assessed in a great many factorial models. Unlike the other dimensions, there is consensus about its definition as the pervasive experience of negative emotions whatever the objective level of threat posed by a situation (Watson \& Clark, 1984). Emotional stability, its positive pole, is regarded as a behavioral inhibition system, controlling our sensitivity to aversive stimuli and the way we react to them (Davidson, 1998). 
As such, it can be defined as a system for controlling the production of "negative" or "unpleasant" emotions.

Neuroticism is associated with deviant workplace behaviors (Skarlicki, Folger, \& Tesluk, 1999), whereas emotional stability promotes training success by reinforcing individuals' motivation to learn (Kappe \& Van der flier, 2010). For example, a seven-year longitudinal study showed that neuroticism was the most accurate predictor of subjective distress both inside and outside the workplace (Ormel \& Wolfarth, 1991). Individuals with high levels of neuroticism and low levels of extraversion appear to display more emotional disorders (Lung, Lee, \& Shu, 2006). Neuroticism is associated with the adopting of emotionfocused disengagement coping strategies, in particular problem avoidance and self-criticism, rather than more efficient, problem-solving strategies (Endler \& Parker 1990); in a naval context (Sandal, Endresen, Vaernes, \& Ursin, 1999).

It just so happens that navy recruiters have been looking for a scale that enables them to assess individuals on their abilities to cope with depression, stress and anxiety, and manage their anger and impulsiveness. In many line jobs, the volume of information that has to be processed, the nature of the tasks that have to be performed and the situations that individuals have to deal with can generate a great deal of stress, hence the need to assess this aspect during the selection process. Given that many posts place considerable constraints on sailors (e.g., working in confined spaces, repetitive tasks) and most jobs involve teamwork, recruiters also need to gauge applicants' levels of impulsiveness and irascibility. In order to assess Emotional Stability, we therefore chose two facets that are not only central to the FFM in theoretical terms, but are also broadly in line with the definitions provided above. These are "Serenity vs. Anxiety/Depression", which corresponds to the anxiety, depression and vulnerability facets in Costa and McCrae (1992)'s model, and "Self-control vs. Anger/Impulsiveness", which seems particularly relevant in the context of navy recruiting. 
Extraversion. While McCrae and Costa (1987) likened extraversion to sociability, gregariousness and dynamism, Goldberg (1990) associated this dimension with ascendancy and ambition. We chose the last one because it is more accurate with the navy's needs and because Hogan and Holland (2003) find that ambition, not sociability, predict work success. This construct is close to the notion of assertiveness in the FFM. For example, Bartone, Snook, and Tremble (2002) demonstrated the importance of assessing leadership in a military context, and "Leadership/ assertiveness" is one of the two facets encompassed by the TAMIP's Ascendancy dimension (tag E in tables), the other being "competitive spirit". Companies mainly use personality tests for recruiting technicians and executives who are likely to find themselves supervising employees within a very short space of time, and in such circumstances, these two facets can prove particularly telling. Further, a study by Hogan and Hogan (1989) on reliability in the workplace showed that extraverted employees are more reliable and punctual. The extraversion dimension predicts performance in posts involving frequent social contacts with others (Salgado, 1999). Strongly extraverted employees engage mainly in problem-focused coping (Parkes, 1986) and positive thinking, making extensive use of strategies for seeking social support (O’Brien \& Delongis, 1996) that are particularly efficient in the workplace.

Openness. The openness dimension can vary both in content and label. It goes under the name of intellect in Goldberg (1990), culture in Norman (1963) and openness to experience in Costa and McCrae (1985). These differences stem mainly from research strategies. Thus, while lexical studies allowed researchers to identify openness to culture and intellectual creativity (Digman, 1990; Goldberg, 1990), in other words, openness to ideas and values, questionnaire-based studies allowed them to extend the notion of openness to emotions, esthetics and the imagination. By carrying out principal component analyses (PCAs) of the six facets of openness to experience contained in the NEO PI-R, Gignac, 
Stough, and Loukomitis (2004) were able to identify two, more general components of openness. All the facets were loaded with the first component, while the second component, referred to as "Objective openness", encompassed the "Actions", "Ideas" and "Values" facets. The usefulness of this typology was demonstrated by examining the convergent validity correlations of each of these two components with general intelligence. The first component was shown to have a positive correlation with general intelligence, but not the second one, which regulates enjoyment of newness and pursuit of intellectual interests (desire to develop or diversify one's cognitive activities). In line with these studies, and drawing on these two subscales, we came up with two facets: "Openness to intellect" and "Openness to change and the imagination". The former was chosen because it predicts successful training or apprenticeship, though not specifically job success (Barrick et al., 1999; Salgado, 1999). Openness to intellect is said to be predictive of better performance by salespeople (Furnham \& Fudge, 2008), the theory being that it makes it easier for them to understand customers' motivations. The latter was more specifically chosen for its relevance to naval selection. It is thought to yield indicators about respondents' desire for change and development and their ability to adjust to new work contexts (taking on extra responsibility, moving to a different department, being transferred). Insofar as it is linked to potential reorganizations, it corresponds closely to Gignac et al.'s "Objective openness" component (2004). Openness is something that is expected of sailors, given that they are transferred every three years. Moreover, this dimension appears to be predictive of leaders' successful adjustment, especially in a military context (McCormack \& Mellor, 2002).

Agreeableness. Relating to the way in which we deal with other people, agreeableness regulates the tone of interpersonal relations, along a spectrum ranging from altruism to self-centeredness. It also influences behavior toward other people in social intercourse and plays a role in the ability to become part of a group, the emergence of 
interpersonal conflict and the management of emotions linked to this conflict (Leblanc, LaFrenière, St-Sauveur et al. 2004). Several studies have demonstrated the link between agreeableness and the quality of interpersonal relations (Costa \& McCrae, 1992). People who behave pleasantly find it far easier to fit in and encounter less conflict, being more concerned with cooperation than with competition (Barrick, Stewart, \& Piotrowski, 2002). Similarly, "agreeable" people develop fewer antisocial behaviors at work than "disagreeable" ones (Leblanc, LaFrenière, St-Sauveur et al. 2004). When associated with a high degree of conscientiousness, agreeableness contributes to better leadership performances (Bartone, Snook, \& Tremble, 2002). Halfhill, Nielsen, Sundstrom, and Weilbaecher (2005), for instance, found that the military service teams that scored the highest on agreeableness and conscientiousness also displayed the greatest effectiveness.

Among the construct of the FFM, we have identified central and useful aspects in a recruitment situation. These are "Confidence", "Altruism" and "Compliance", while "Modesty", "Tendermindedness" and "Straightforwardness" facets in Costa and McCrae (1992)'s model seemed too specific to certain areas of work and less central. On another side, the theoretical choices related to the Ascendency factor (instead of Extraversion), led us to include "Warmth" items in the agreeableness contruct. Indeed, this construct seemed to be best suited to the Navy and to its frequent requirement for teamwork in confined environments. The dimensions selected for the TAMI-P were "Trust/Compliance" and "Warmth/Altruism".

Conscientiousness. The cluster of traits within the conscientiousness factor includes "Organization", "Punctuality", "Thoroughness", "Perseverance", "Ambition", "Moral rectitude", "Scrupulousness" and "Obedience". Some authors add "Need for achievement" (Digman \& Takemoto-Chock, 1981). This dimension has a motivational tone and serves to regulate and control activity and behaviors in order to achieve a more or less long-term goal. 
By so doing, it allows individuals to reign in impulsive behaviors associated with instant gratification and instead delay reward and accept the constraints of the task that is required of them. At the same time, it allows them to devote all their energy to achieving the goal quickly and effectively. It was on this basis that we determined the two TAMI-P facets. The first of these is "Reliability/Perseverance", which incorporates the "Dutifulness", "Achievement striving" and "Self-discipline" facets of Costa and McCrae (1992)'s model. The second is "Organization/Scrupulousness" which incorporates mainly “Order”. These constructs specifically correspond to the skills needs to be adapted to military structure. We believe that these facets are central to the conscientiousness dimension from a theoretical standpoint. Further, they are not only extremely relevant to recruitment, but also have very real implications for life in the Navy, where personnel have to follow orders, instructions and procedures to the letter (Sümer, Sümer, Demirutku, \& Çifci, 2001). Conscientiousness is predictive of academic performance (Kappe \& Van der flier, 2010) and performance in a variety of different jobs (Salgado, 1999). This dimension is positively related to productivity (Barrick, Mount, \& Strauss, 1993). John and Srivastava (1999) claimed that when it is associated with a fairly high level of agreeableness, this dimension is also a good predictor of team-related behavior and performance, which is very important dimension in the Armed Forces. It is also negatively related to absenteeism (Judge, Martocchio, \& Thoresen, 1997), counterproductive behaviors (Driskell, Hogan, Salas, \& Hoskin, 1994) and accident involvement (Clarke \& Robertson, 2005). In their study, Christopher, Zabel, and Jones (2008) demonstrated that the "Dutifulness" and "Competence" facets of the NEO PI-R are associated with the seven dimensions of the work ethic, namely "Hard work", "Work centrality", "Wasted time" (reversed), "Delay of gratification", "Morality/ethics", "Selfreliance" and "Leisure" (reversed). 
To summarize, we sought to construct a French-language personality instrument that could be used for recruitment and career guidance in the French Navy. The instrument was expected to have a hierarchical structure comprised of five factors, each of which would contain two lower order facets (see Table 1). The main objective of this study was to evaluate the structural and psychometric properties of this instrument. Given the theoretically driven nature of our measure we expected that the structural properties of the measure would yield a five-factor solution with 10 facets. With regard to the psychometric properties of the instrument we expected that the five-scale inventory would exhibit comparable internal consistency and test-retest stability estimates as those found in equivalent instruments.

\section{Method}

\section{Data and Procedures}

Data from 1,266 sailors or people seen during recruitment (967 men and 299 women, aged 17-36 years $(M=24 \pm 4.4)$ were used for analyses. The inventory was administered either during recruitment (57\%), career guidance (4\%) or vocational training (39\%). To test convergent validity, in the same testing session, 681 participants (473 men and 208 women, aged 18-35 years $(M=23 \pm 4.1))$ completed the BFQ questionnaire and 118 (103 men and 15 women, aged $18-34$ years $(M=23 \pm 3.4))$ the NEO PI-R. In order to measure test-retest reliability, 145 trainee sailors filled in the questionnaire a second time after an interval varying between 22 and 34 days $(M=29.3 \pm 4.8)$. It is worth noting that the sample used for the study was comparable to candidates and sailors presenting at selection and orientation in the French Navy.

\section{Measures}

TAMI-P. The TAMI-P contains 70-items designed to assess each of 10 facets of personality that cluster around five factors which include Serenity vs. Anxiety/Depression (e.g., "I sometimes get very worried even though the situation doesn't really warrant it") and 
Self Control vs. Anger/Impulsiveness (e.g., "Some situations make me see red") for Emotional Stability (ES); Leadership/Assertiveness (e.g., "I let other people take the decisions") and Competitive Spirit (e.g., "Power games encourage me to give the best of myself") for Ascendancy (E); Openness to Intellect (e.g., "I like to tackle puzzles and logic games") and Openness to Change and Imagination for Openness (e.g., "My friends and relatives say I have a vivid imagination") for Openness; Trust/Compliance (e.g., "I trust nobody but myself") and Warmth/Altruism (e.g., "I am attentive to others and I anticipate their needs") for Agreeableness; Reliability/Perseverance (e.g., "When I do something, I like to do it properly and see it through the end") and Organization/Scrupulousness (e.g., "I like things to be put back in their proper place") for Conscientiousness. All scales were counterbalanced so that approximately $30 \%$ of items within each scale were negatively worded to avoid response bias. Instructions asked respondents to rate each statement using a 5-point response scale ranging from "this statement does not describe me at all or is completely wrong" (1) to "this statement describes me completely or is entirely true" (5).

We also included the BFQ (Caprara \& al. 1993) and the NEO PI-R (Costa \& MC Crae, 1992) to enable us to examine the convergent validity of the TAMI-P. We selected these instruments because they were theoretically consistent with the TAMI-P and are among the most widely used instruments to assess personality constructs by French companies. The BFQ (Caprara \& al. 1993) and the NEO PI-R (Costa \& MC Crae, 1992) include multi-item scales designed to assess each of the five personality dimensions. Items are presented in Likert-type format with a scale ranging from strongly disagree (1) to strongly agree (5). Scale scores were computed by reverse scoring appropriate items and averaging across items, with higher scores indicating a greater endorsement of items within each facet of personality contained within the BFQ and the NEO PI-R. 


\section{Results}

We performed Principal Components Analyses (PCA) to examine the structural properties of the TAMI-P and correlation analyses to examine the convergent and predictive validity of TAMI-P with both the BFQ and the NEO PI-R. Before performing our analyses, we reverse-coded all items assessing neuroticism to facilitate interpretation of scores within the Emotional Stability factor.

\section{Factorial Structure}

A five-factor PCA analysis with orthogonal rotation was performed on the 80 item inventory. As shown in Table 2, the PCA yielded a five-factor, hierarchical structure that was consisted with our hypothesized model. Although secondary factor loadings occurred, these were consistent with reports in the literature $(<0.40)$. The first factor, labeled emotional stability, accounted for $16 \%$ of the total variance. Its two facets were "Serenity versus anxiety/depression" and "Self-control versus hostility/impulsiveness". The former assessed the manner in which individuals perceive and control states of tension linked to life experiences described as difficult or stressful, yielding information about how people experience emotions such as anxiety, stress and panic states, and periods of solitude and sadness. The latter measured the respondent's general ability to control his or her behavior with a view to assessing the individual's propensity to feel emotions such as anger, rage or aggressiveness.

The second factor, labeled ascendancy, accounted for $15 \%$ of the total variance. Its two facets were "Leadership/assertiveness " and "Competitive spirit". The former assessed individuals on the basis of ascendancy in decision-taking, ability to manage and/or steer group activities, and/or power of persuasion. The latter probed respondents' liking for competitive situations both in the workplace and in leisure activities, as well as their attraction to situations offering them an opportunity to surpass themselves and pit themselves 
against other people. The third factor, labeled openness, accounted for $13 \%$ of the variance. The first facet, "Openness to intellect", measured general openness to culture. At its positive pole, it corresponded to a marked interest in the acquisition of new knowledge, reading and philosophical discussion, plus a desire to be well-informed. The second facet, "Openness to change and the imagination", reflected a favorable disposition toward newness and change, as well as attraction to the imagination, in the sense that it offers an opportunity to indulge in creativity, personal fulfillment and/or reflection. These two facets are reminiscent of the two general components of the openness/intellect factor described by Gignac et al. (2004), the former recalling "Objective openness", the latter "Intellect".

The fourth factor, labeled agreeableness, accounted for $14 \%$ of the explained variance. The first of its two facets, "Trust/compliance", assessed the extent to which the respondent trusted other people and his or her ability to make contact and cooperate. The second facet, "Warmth/Altruism", contained items relating to different types of interindividual contacts, probing qualities such as joviality and compassion in interpersonal relations. The fifth factor, labeled conscientiousness, accounted for $15 \%$ of the explained variance. The first facet, "Reliability/perseverance," probed the steadfastness and perseverance displayed by respondents when carrying out their missions and their degree of circumspection. The second facet, "Organization/scrupulousness," related to organization and methodicalness of individuals.

\section{Reliability Analyses}

Internal consistency. We estimated internal consistency estimates using Cronbach's alpha (see Table 3). The process of reducing the number of items during the analysis phase was halted as soon as the scale showing the weakest internal consistency dropped below the recommended threshold of .70 . We believed it was important to observe this stringent level in order to allow for one or two nonresponses for each facet without unduly impairing 
measurement quality. Despite the small number of items, the inventory had entirely satisfactory homogeneity indices, ranging from .70 to .88 , although three facets had an internal consistency of below .75: "Openness to change and the imagination" and "Reliability/perseverance".

Test-Retest Reliability. We also estimated test-retest reliability using data from 145 trainees that completed measures approximately 22-34 days after our initial assessment (see Table 3). Correlational analyses indicated that 5 of the 10 facets had a high level of stability (> .80), with only "Reliability/perseverance" displaying a weak coefficient (.66). Validity Analyses

Inter-Factor Correlations. We computed a correlation matrix to examine the relationships among the five factors included in the TAMI-P (see Table 4). The correlations between the factors were relatively homogeneous, ranging from .24 to 0.41 . The highest inter-factor correlation was observed between emotional stability and agreeableness, estimated at .41 .

Convergent validity. We computed correlations between TAMI-P, BFQ and NEO PI$\mathrm{R}$ to examine convergence validity of the TAMI-P. In line with our expectations, we observed relatively high positive correlations between the TAMI-P, BFQ and NEO PI-R factors (see Table 5). There appeared to be greater convergence between the TAMI-P and NEO PI-R than between the TAMI-P and BFQ. For the latter, most of the correlations ranged between .53 (agreeableness) and .68 for the convergent factors and were below .35 for the divergent ones. For the former, correlations varied between .47 (ascendancy) and .84 for the convergent factors and were below .49 for the divergent factors. It should be noted that the ascendancy scale in the TAMI-P includes items relating to leadership/assertiveness and competitive spirit, whereas in the NEO PI-R, this dimension contains facets relating to activity, excitement-seeking and positive emotions. The correlation of .47 between 
extraversion and ascendency is consistent with our expectations and the construct chosen for the TAMI-P. Indeed, we are oriented to a more accurate assessment of assertiveness close to Golberg (1990) and thus less close to the FFM. On the other hand, the correlation of .49 between the NEO PI-R extraversion and agreeableness of TAMI-P also follows our theoretical choices. In wanting to keep the items of "warmth" and integrate them in agreeableness, we amalgamated the two dimensions and thus amplified their correlation; that are initially already quite strong in the FFM (Costa and McCrae, 1992).

Following Ekehammar and Akrami (2007)'s example, we analyzed the correlations between the facets of the TAMI-P and those of the NEO PI-R, in order to fine-tune the former's convergent validity and confirm our initial postulates. As can be seen in Table 6, these results matched DeYoung et al. (2007)'s findings and confirmed our hypotheses concerning the construction of this assessment instrument. For the emotional stability dimension, the "Serenity versus anxiety/depression" facet correlated negatively with the "Anxiety", "Depression" and "Vulnerability" facets of Costa and McCrae (1992)'s model, while "Self-control versus anger/impulsiveness" was closer to "Angry hostility". For ascendancy, there was a close link between "Leadership/assertiveness" and "Assertiveness", which is particularly important in recruitment, while "Competitive spirit" was most closely linked to the NEO PI-R'S "Activity" facet (.50 which is lower than the correlation of .45 with "Achievement-Striving"of the FFM model). As far as the openness factor is concerned, the closest correlations were between "Openness to intellect" and "Openness to ideas", and between "Openness to change and the imagination" and "Openness to fantasy", "Openness to feelings" and, to a lesser degree, "Openness to actions". This can be explained by the fact that the content of the TAMI-P'S "Openness to change and the imagination" items is similar to that of the items in the NEO PI-R scales. For agreeableness, there were strong correlations between "Trust/compliance" and "Trust", and between "Warmth/Altruism" and "Altruism". 
The correlation between "Warmth/Altruism" and "Warmth" is nevertheless strong (0.79). In line with our hypotheses, the "Reliability/perseverance" facet of conscientiousness correlated with three of the NEO PI-R facets ("Dutifulness", "Achievement striving" and "Selfdiscipline"), while the "Organization/scrupulousness" facet was linked to "Order".

\section{Ancillary Analyses Examining Gender Differences}

When constructing a personality inventory, it is important to take sex differences into account, as psychological tests can yield different profiles according to gender. Our analyses revealed a sex difference for the emotional stability dimension, $t(1,266)=3.14, p<0.01$, which can probably be attributed to women's greater emotional sensitivity (Diener, Sandvik, \& Larsen, 1985). Further, while women on average scored lower than men on the ascendancy dimension, $t(1,266)=2.75, p<0.01$, they scored noticeably higher on both openness, $t(1,266)=4.21, p<0.01$, and conscientiousness, $t(1,266)=4.21, p<0.01$. The only factor where there was no sex effect was agreeableness. These results suggest that specific norms may need to be constructed for each gender. Accordingly, we constructed six norms to distinguish responses of men and women in the Officers, Non-Commisioned Officers (NCO) and enlisted ranks.

\section{Discussion}

The aim of the present study was to contruct new assessment instrument specific for recruitment requirements and the need to provide mid-career guidance for officers and NonCommissioned Officers for all the French Armed Forces. This model was selected to test the validity of theoretical structure based on the model of personality between the narrow facets and the broad domain. The optimal facet-level of personality in five factor model is still unknown and this intermediate hierarchy between facets and domains seem to be very interesting in the military context. 
Closely mirroring this model, a personality assessment inventory was designed, named TAMI-P, with ten facets reliable and valid: "Serenity versus anxiety/depression" and "Self-control versus anger/impulsiveness" for emotional stability; "Warmth/Altruism" and "Trust/compliance" for agreeableness; "Organization/scrupulousness" and "Perseverance/reliability" for conscientiousness; "Competitive spirit" and "Leadership/assertiveness" for ascendancy; "Openness to change and the imagination" and "Openness to intellect" for openness. This instrument was also designed to meet the French Navy's specific recruitment requirements and the need to provide mid-career guidance for officers and Non-Commissioned Officers.

In psychometric terms, an analysis of the main components revealed that the inventory complied with the principle of parsimony. The highest secondary factor loadings were only moderate and way below the lowest primary loadings. None of the facets could therefore be regarded as belonging to more than one factor. Despite the small number of items, the testretest reliability indices of the TAMI-P were all satisfactory, bar one. Above and beyond these internal qualities, there was a good level of convergent validity between the TAMI-P and the BFQ and NEO PI-R. Correlations ranged from .53 to $.62(p>0.01)$ for the TAMI-P and BFQ factors and from .47 to .84 for the TAMI-P and NEO PI-R factors. All the differences we observed could be justified by differences in content, especially for the ascendancy factor. In line with our hypotheses, the TAMI-P appeared to have more similarities with Costa and McCrae (1992)'s model than with that of Caprara et al. (1993). For the factor emotional stability, conscientiousness and openness, the relations between factors correspond to our theoretical hypotheses and our choices about adjustment constructs of the FFM in the context of military selection. The facets of TAMI-P correlate with those of the NEO PI-R and conform with our hypotheses. However, two major differences appear between the FFM and TAMI-P models. They are exclusively associated with theoretical choices made to 
adjust the structure to the specific needs of military recruitment. The first difference concerns the extraversion factor, named ascendency in the TAMI-P, which approximates the concept of ambition and ascendancy of Goldberg (1990). The TAMI-P does not include a construct for the activity, dynamics and positive emotions as in the FFM. Moreover, the integration of "Competitive Spirit"construct, which aims to get close to the specific needs of the military recruitment also appears to be related to the "Achievement-Striving" placed by Costa $\&$ McCrae (1992) in Conscientiousness dimension. The second difference with the model is relative to agreeableness FFM factor. In the TAMI-P, this dimension includes a facet Warmth which is related to extraversion factor in the FFM. During construction of the TAMI-P, theoretical orientation taken to focus on assertiveness in the extraversion factor has led to highlight the facet "Warmth" in agreeableness (by uniting to items related to altruism). The internal consistency of items in this scale are quite robust (.84) and the factor structure generally consistent with our expectations. Previous work on the FFM shows obvious correlations between extraversion and agreeableness.

The predictive validity of the BIG FIVE in job performance was developed much in this article to demonstrate utility for personnel selection. The TAMI-P's predictive validity for job success is currently being analyzed on careful consideration of the expected theoretical or conceptual relations between the personality predictor and performance criterion of interest, as well as appropiate level of analysis between predictor and criterion measures specific to the military contexts (Rothstein \& Gollin, 2006). One of the most important aspects of our future research is to analyze of the dynamic relationship between personality and situations to explain how personality acts upon inter- and intraindividual differences in the way that individuals cope with different situations, as well as in the behaviors they display (Fok, Hui, Harris Bond, Matsumoto, \& Yoo, 2008). This type of approach makes it possible to identify the particular relationship that exists between personality, situation and behavior and the 
potential moderator and mediator effect due to situationally specific nature of personality predictors (Rothstein \& Gollin, 2006).

Interest in personality in general and the BIG FIVE model in particular is not restricted to the workplace, and numerous studies have identified relationships between personality traits and behaviors that are either beneficial or detrimental to health, as well as links with clinical psychology and psychiatry (Costa \& Widiger, 1994; 2002, O’Connor, 2002). Ostendorf (2002) produced an overview of 43 studies looking at the links between personality disorders and the five domains of the FFM. This meta-analysis clearly showed that the psychopathological syndromes classified under Axis II of the DSM-III-R and DSM-IV intersect with four dimensions of the FFM (N, E, A, C). De Fruyt et al., (2009) examined whether trait models used to study personality dysfunction may be useful for personnel selection assessment and career coaching and development. They found that personality dysfunction was related to important criteria in selection and professional development assessments (final selection decision, results of behaviorally oriented selection interview and self-rated work competencies). As these issues are also of concern to the military organizations (Lung, Lee, \& Shu, 2006), the TAMI-P could, perhaps, prove useful in contexts other than those for which it was originally intended. This work could provide guidelines for screening for potential dysfunction patterns in individuals applying for jobs or seeking career counselling (De Fruyt et al., 2009) and could help to predict the maladjustement of military exposed to operational events.

Personality tests are routinely administered to adolescents (the main target of army recruiters), and it would be interesting to analyze the developmental changes that take place in this age group. Adolescent personality varies over time (Caspi, Roberts, \& Shiner, 2005; Soto, John, Gosling, \& Potter, 2008; Klimstra, Hale, Raaijmakers, Branje, \& Meeus, 2009), and a study of these fluctuations could yield useful information on which to base our 
interpretations. Longitudinal studies could be used to pinpoint when and where personality stabilizes and when is it necessarry to increase psychological maturity over development, from adolescence to middle age and analyze consequences of adjustment within military context.

\section{Conclusion}

The TAMI-P appears to have a theoretically sound structure, strong psychometric properties and can be completed within just 15-20 minutes. The TAMI-P has been normed to allow comparisons to be made for men and women in the Officer, Non-Commissioned Officer and Enlisted ranks. All the French Armed Forces on the first level of selection will soon use the TAMI-P. The theoretically driven nature of the TAMI-P provides the French Armed Forces with the opportunity to assess personality for not only personnel selection or guidance purposes but also for clinical and behavioural health assessments. 


\section{References}

Ashton, M. C., Lee, K., Perugini, M., Szarota, P., de Vries, R. E., Di Blas, L., \& ... De Raad, B. (2004). A Six-Factor Structure of Personality-Descriptive Adjectives: Solutions From Psycholexical Studies in Seven Languages. Journal of Personality and Social Psychology, 86(2), 356-366.

Barrick, M. R., \& Mount, M. K. (1991). The Big Five personality dimensions and job performance: A meta-analysis. Personnel Psychology, 44(1), 1-26.

Barrick, M. R., Mount, M. K., \& Judge, T.A. (1999). The FFM personality dimensions and job performance: A meta-analysis of meta-analyses. Paper presented at the 14th Annual Conference of the Society for Industrial and Organizational Psychology, Atlanta, GA.

Barrick, M. R., Mount, M. K., \& Strauss, J. P. (1993). Conscientiousness and performance of sales representatives: Test of the mediating effects of goal setting. Journal of Applied Psychology, 78(5), 715-722.

Barrick, M. R., Stewart, G. L., \& Piotrowski, M. (2002). Personality and job performance: Test of the mediating effects of motivation among sales representatives. Journal of Applied Psychology, 87(1), 43-51.

Bartone, P. T., Snook, S. A., \& Tremble, T. r. (2002). Cognitive and personality predictors of leader performance in West Point cadets. Military Psychology, 14(4), 321-338.

Caprara, G., Barbaranelli, C., Borgogni, L., \& Perugini, M. (1993). The 'Big Five Questionnaire': A new questionnaire to assess the Five Factor Model. Personality and Individual Differences, 15(3), 281-288.

Caspi, A., Roberts, B. W., \& Shiner, R. L. (2005). Personality Development: Stability and Change. Annual Review of Psychology, 56, 453-484. 
Christopher, A. N., Zabel, K. L., \& Jones, J. R. (2008). Conscientiousness and work ethic ideology: A facet-level analysis. Journal of Individual Differences, 29(4), 189-198.

Clarke, S., \& Robertson, I. T. (2005). A meta-analytic review of the Big Five personality factors and accident involvement in occupational and non-occupational settings. Journal of Occupational \& Organizational Psychology, 78(3), 355-376.

Costa, P. T., \& McCrae, R. R. (1985). The NEO personality inventory manual. Odessa, FL: Psychological Assessment Resources.

Costa, P. T., \& McCrae, R. R. (1992). Revised NEO Personality Inventory (NEO-PI-R) and NEO Five-Factor Inventory (NEO-FFI) professional manual. Odessa, FL: Psychological Assessment Resources.

Costa, P. (Ed.), \& Widiger, T. (Ed.). (1994). Personality disorders and the five-factor model of personality. Washington, DC US: American Psychological Association.

Costa, P. (Ed.), \& Widiger, T. (Ed.). (2002). Personality disorders and the five-factor model of personality (2nd ed.). Washington, DC US: American Psychological Association.

Davidson, R. J. (1998). Affective Style and Affective Disorders: Perspectives from Affective Neuroscience. Cognition \& Emotion, 12(3), 307-330.

De Fruyt, F., De Clercq, B. J., Miller, J., Rolland, J., Jung, S., Taris, R., \& ... Van Hiel, A. (2009). Assessing personality at risk in personnel selection and development. European Journal of Personality, 23(1), 51-69.

DeYoung, C. G. (2006). Higher-order factors of the Big Five in a multi-informant sample. Journal of Personality and Social Psychology, 91(6), 1138-1151.

DeYoung, C. G., Quilty, L. C., \& Peterson, J. B. (2007). Between facets and domains: 10 aspects of the Big Five. Journal of Personality and Social Psychology, 93(5), 880896. 
Diener, E., Sandvik, E., \& Larsen, R. J. (1985). Age and sex effects for emotional intensity. Developmental Psychology, 21(3), 542-546.

Digman, J. M. (1990). Personality structure: Emergence of the five-factor model. Annual Review of Psychology, 41(1), 417-440.

Digman, J. M., \& Takemoto-Chock, N. K. (1981). Factors in the natural language of personality: Reanalysis and comparison of six major studies. Multivariate Behavioral Research, 16(2), 149-170.

Driskell, J. E., Hogan, J., Salas, E., \& Hoskin, B. (1994). Cognitive and Personality Predictors of Training Performance. Military Psychology, 6(1), 31-46.

Ekehammar, B., \& Akrami, N. (2007). Personality and Prejudice: From Big Five Personality Factors to Facets. Journal of Personality, 75(5), 899-926.

Endler, N. S., \& Parker, J. D. (1990). Multidimensional assessment of coping: A critical evaluation. Journal of Personality and Social Psychology, 58(5), 844-854.

Fok, H., Hui, C., Bond, M., Matsumoto, D., \& Yoo, S. (2008). Integrating personality, context, relationship, and emotion type into a model of display rules. Journal of Research in Personality, 42(1), 133-150.

Furnham, A., \& Fudge, C. (2008). The Five Factor model of personality and sales performance. Journal of Individual Differences, 29(1), 11-16.

Gignac, G. E., Stough, C., \& Loukomitis, S. (2004). Openness, intelligence, and self-report intelligence. Intelligence, 32(2), 133-143.

Goldberg, L. R. (1990). An alternative "description of personality": The Big-Five factor structure. Journal of Personality and Social Psychology, 59(6), 1216-1229.

Goldberg, L. R. (1993). The structure of phenotypic personality traits. American Psychologist, 48(1), 26-34. 
Halfhill, T., Nielsen, T. M., Sundstrom, E., \& Weilbaecher, A. (2005). Group Personality Composition and Performance in Military Service Teams. Military Psychology, 17(1), $41-54$

Hogan, R. (1996). Personality assessment. In R. S. Barrett, R. S. Barrett (Eds.), Fair employment strategies in human resource management (pp. 144-152). Westport, CT US: Quorum Books/Greenwood Publishing Group.

Hogan, J., \& Hogan, R. (1989). How to measure employee reliability. Journal of Applied Psychology, 74, 273-279.

Hogan, J., \& Holland, B. (2003). Using theory to evaluate personality and job-performance relations: A socioanalytic perspective. Journal of Applied Psychology, 88(1), 100112.

John, O. P., \& Srivastava, S. (1999). The Big Five Trait taxonomy: History, measurement, and theoretical perspectives. In L. A. Pervin, O. P. John, L. A. Pervin, O. P. John (Eds.), Handbook of personality: Theory and research (2nd ed.) (pp. 102-138). New York, NY US: Guilford Press.

Judge, T. A., \& Higgins, C. A. (1999). The big five personality traits, general mental ability, and career success across the life span. Personnel Psychology, 52(3), 621-652.

Judge, T. A., Martocchio, J. J., \& Thoresen, C. J. (1997). Five-factor model of personality and employee absence. Journal of Applied Psychology, 82(5), 745-755.

Kappe, R., \& van der Flier, H. (2010). Using multiple and specific criteria to assess the predictive validity of the big five personality factors on academic performance. Journal of Research in Personality, 14(1), 142-145.

Klimstra, T. A., Hale, W. W., Raaijmakers, Q. A., Branje, S. J., \& Meeus, W. H. (2009). Maturity of personality in adolescence. Journal of Personality and Social Psychology, 96(4), 898-912. 
Leblanc, G. G., LaFrenière, A. A., St-Sauveur, C. C., Simard, M. M., Duval, M. M., LeBrock, P. P., \& ... Savoie, A. A. (2004). Explication des comportements antisociaux au travail: Présentation d'un modèle intégratif. Psychologie du Travail et des Organisations, 10(1), 61-73.

Lung, F., Lee, F., \& Shu, B. (2006). The premorbid personality in military students with adjustment disorder. Military Psychology, 18(1), 77-88.

McCormack, L., \& Mellor, D. (2002). The Role of Personality in Leadership: An Application of the Five-Factor Model in the Australian Military. Military Psychology, 14(3), 179197.

McCrae, R. R., \& Costa, P. T. (1987). Validation of the five-factor model of personality across instruments and observers. Journal of Personality and Social Psychology, 52(1), 81-90.

McCrae, R. R., \& John, O. P. (1992). An Introduction to the Five-Factor Model and its Applications. Journal of Personality, 60(2), 175-215.

McCrae, R. R., Yamagata, S., Jang, K. L., Riemann, R., Ando, J., Ono, Y., \& ... Spinath, F. M. (2008). Substance and artifact in the higher-order factors of the Big Five. Journal of Personality and Social Psychology, 95(2), 442-455.

Mount, M. K., \& Barrick, M. R. (1998). Five reasons why the 'Big Five' article has been frequently cited. Personnel Psychology, 51(4), 849-857.

Norman, W. T. (1963). Toward an adequate taxonomy of personality attributes: Replicated factor structure in peer nomination personality ratings. The Journal of Abnormal and Social Psychology, 66(6), 574-583.

O'Brien, T., \& DeLongis, A. (1996). The Interactional Context of Problem-, Emotion-, and Relationship-Focused Coping: The Role of the Big Five Personality Factors. Journal of Personality, 64(4), 775-813. 
O'Connor, B. P. (2002). The search for dimensional structure differences between normality and abnormality: A statistical review of published data on personality and psychopathology. Journal of Personality and Social Psychology, 83(4), 962-982.

Ormel, J., \& Wohlfarth, T. (1991). How Neuroticism, Long-Term Difficulties, and Life Situation Change Influence Psychological Distress : A Longitudinal Model. Journal of Personality and Social Psychology, 60, 744-755.

Ostendorf, F. (2002, July). Generalizability of the relationships between personality disorders and the Big-Five factors of personality. In T. A. Widiger \& F. Ostendorf (Organizers), Personality and personality disorders. Symposium conducted at the 11th European Conference on Personality, Jena, Germany.

Parkes, K. R. (1986). Coping in stressful episodes: The role of individual differences, environmental factors, and situational characteristics. Journal of Personality and Social Psychology, 51(6), 1277-1292.

Rothstein, M. G., \& Goffin, R. D. (2006). The use of personality measures in personnel selection: What does current research support?. Human Resource Management Review, 16(2), 155-180.

Rushton, J., Irwing, P., \& Booth, T. (2010). A general factor of personality (GFP) in the personality disorders: Three studies of the Dimensional Assessment of Personality Pathology_Basic Questionnaire (DAPP-BQ). Twin Research and Human Genetics, 13(4), 301-311.

Salgado, J. F. (1999). Personnel selection methods. In C. L. Cooper, I. T. Robertson, C. L. Cooper, I. T. Robertson (Eds.), International review of industrial and organizational psychology 1999, Vol. 14 (pp. 1-54). New York, NY US: John Wiley \& Sons Ltd.

Sandal, G. M., Endresen, I. M., Vaernes, R., \& Ursin, H. (1999). Personality and Coping Strategies During Submarine Missions. Military Psychology, 11(4), 381-403. 
Schmidt, F. L., \& Ones, D. S. (1992). Personnel selection. Annual Review of Psychology, 48(1), 299-337.

Soto, C. J., John, O. P., Gosling, S. D., \& Potter, J. (2008). The developmental psychometrics of big five self-reports: Acquiescence, factor structure, coherence, and differentiation from ages 10 to 20. Journal of Personality and Social Psychology, 94(4), 718-737.

Skarlicki, D. P., Folger, R., \& Tesluk, P. (1999). Personality as a moderator in the relationship between fairness and retaliation. Academy of Management Journal, 42(1), 100-108.

Sümer, H., Sümer, N., Demirutku, K., \& Çifci, O. (2001). Using a Personality-Oriented Job Analysis to Identify Attributes to Be Assessed in Officer Selection. Military Psychology, 13(3), 129-146.

Watson, D., \& Clark, L. A. (1984). Negative affectivity: The disposition to experience aversive emotional states. Psychological Bulletin, 96(3), 465-490. 
Table 1. Theoretical Factors and Facets for the TAMI-P with Trait Descriptors and Occupations Concerned with Trait

\begin{tabular}{|c|c|c|c|c|}
\hline \multicolumn{2}{|c|}{ Names of factors and facets } & \multicolumn{2}{|c|}{$\begin{array}{c}\text { Theoretical hypotheses and trait } \\
\text { definitions }\end{array}$} & \multirow{2}{*}{$\begin{array}{c}\begin{array}{c}\text { Specific recruitment } \\
\text { objectives }\end{array} \\
\text { Type of job particularly } \\
\text { concerned by this trait }\end{array}$} \\
\hline Factors & Facets & $\begin{array}{c}\text { Typical } \\
\text { descriptive traits } \\
\text { Positive pole } \\
\end{array}$ & $\begin{array}{c}\text { Typical descriptive } \\
\text { traits } \\
\text { Negative pole } \\
\end{array}$ & \\
\hline \multirow{2}{*}{ 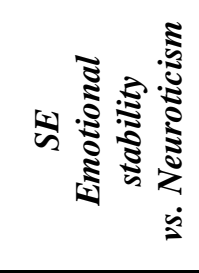 } & $\begin{array}{c}\text { Serenity vs. anxiety } \\
/ \\
\text { depression }\end{array}$ & $\begin{array}{l}\text { Calm, relaxed, } \\
\text { stable, even- } \\
\text { tempered }\end{array}$ & $\begin{array}{c}\text { Anxious, depressed, } \\
\text { tense, } \\
\text { vulnerable }\end{array}$ & \multirow{2}{*}{$\begin{array}{l}\text { Occupations requiring a } \\
\text { high level of resistance to } \\
\text { stress and frustration }\end{array}$} \\
\hline & $\begin{array}{l}\text { Self-controls. } \\
\text { anger / } \\
\text { impulsiveness }\end{array}$ & $\begin{array}{l}\text { Moderate, good- } \\
\text { natured, rarely } \\
\text { impulsive }\end{array}$ & $\begin{array}{c}\text { Irascible, impulsive, } \\
\text { preoccupied }\end{array}$ & \\
\hline \multirow{2}{*}{ 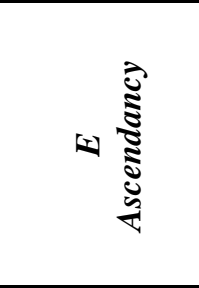 } & $\begin{array}{l}\text { Leadership/ } \\
\text { assertiveness }\end{array}$ & $\begin{array}{l}\text { Good manager, } \\
\text { assertive, } \\
\text { dominant, } \\
\text { convincing, } \\
\text { articulate }\end{array}$ & $\begin{array}{l}\text { Withdrawn, } \\
\text { submissive, a follower, } \\
\text { inhibited }\end{array}$ & \multirow{2}{*}{$\begin{array}{l}\text { Jobs requiring a wide } \\
\text { diversity of contacts with } \\
\text { other people, involving the } \\
\text { supervision of a team or } \\
\text { project, and requiring } \\
\text { managerial skills and } \\
\text { powers of persuasion }\end{array}$} \\
\hline & Competitive spirit & $\begin{array}{l}\text { Ambitious, } \\
\text { competitive }\end{array}$ & $\begin{array}{c}\text { Indifferent to } \\
\text { competition }\end{array}$ & \\
\hline \multirow{2}{*}{$0 \underset{0}{0}$} & $\begin{array}{l}\text { Openness to } \\
\text { intellect }\end{array}$ & $\begin{array}{l}\text { Open to culture } \\
\text { and to ideas, } \\
\text { broad-minded, } \\
\text { curious }\end{array}$ & $\begin{array}{l}\text { Not open to intellect, } \\
\text { simple and down-to- } \\
\text { earth reasoning, } \\
\text { narrow-minded }\end{array}$ & \multirow{2}{*}{$\begin{array}{l}\text { Jobs requiring regular } \\
\text { contacts with people from } \\
\text { very different backgrounds. } \\
\text { Jobs requiring creativity } \\
\text { and openness to newness } \\
\text { and change }\end{array}$} \\
\hline & $\begin{array}{l}\text { Openness to } \\
\text { change and the } \\
\text { imagination }\end{array}$ & $\begin{array}{l}\text { Imaginative, } \\
\text { creative, open to } \\
\text { experience and } \\
\text { change }\end{array}$ & $\begin{array}{l}\text { Set in one's ways, } \\
\text { lacking imagination } \\
\text { and creativity }\end{array}$ & \\
\hline \multirow{2}{*}{ 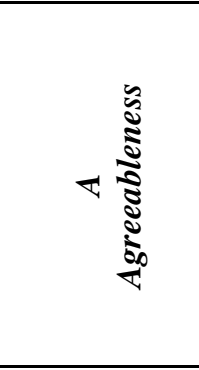 } & Trust/compliance & $\begin{array}{c}\text { Trusting, } \\
\text { warm, likeable, } \\
\text { kind, friendly, } \\
\text { conciliatory, } \\
\text { tolerant }\end{array}$ & $\begin{array}{l}\text { Malicious, } \\
\text { hostile, selfish }\end{array}$ & \multirow{2}{*}{$\begin{array}{l}\text { Jobs involving } \\
\text { interpersonal relations, } \\
\text { where the ability to listen } \\
\text { and provide support is very } \\
\text { important and/or where } \\
\text { members of the public have } \\
\text { to be greeted with warmth } \\
\text { and compassion }\end{array}$} \\
\hline & Warmth/Altruism & $\begin{array}{c}\text { Generous, Open to } \\
\text { others } \\
\text { Compassionate, } \\
\text { Jovial }\end{array}$ & $\begin{array}{c}\text { Selfish, } \\
\text { Indifferent, unfriendly, } \\
\text { cold, } \\
\text { distant }\end{array}$ & \\
\hline \multirow{2}{*}{ u } & $\begin{array}{l}\text { Reliability / } \\
\text { perseverance }\end{array}$ & $\begin{array}{c}\text { Reliable, } \\
\text { persevering, } \\
\text { efficient, } \\
\text { self-disciplined }\end{array}$ & $\begin{array}{l}\text { Unreliable, lacking } \\
\text { stamina, undisciplined }\end{array}$ & \multirow{2}{*}{$\begin{array}{l}\text { All types of jobs and all } \\
\text { types of selection. In } \\
\text { particular, occupations } \\
\text { requiring care, } \\
\text { scrupulousness and } \\
\text { organization }\end{array}$} \\
\hline & $\begin{array}{l}\text { Organization / } \\
\text { scrupulousness }\end{array}$ & $\begin{array}{l}\text { Conscientious, } \\
\text { organized, } \\
\text { responsible, } \\
\text { scrupulous }\end{array}$ & $\begin{array}{l}\text { Inconsistent, } \\
\text { disorderly, } \\
\text { poor planner }\end{array}$ & \\
\hline
\end{tabular}


Table 2: PCA of the 10 facets with orthogonal rotation

SCALES

$\begin{array}{lllll}\text { SE } & \text { E } & \text { O } & \text { A } & \text { C }\end{array}$

Emotional Stability (SE)

Serenity vs. Anxiety/Depression

0.79 0.29

Self-Control vs. Anger/Impulsiveness

0.84

Ascendancy (E)

Leadership

Competitive Spirit

Openness $(\mathbf{O})$

Change/Imagination

Intellect

0.30

$\begin{array}{ll}0.67 & 0.34\end{array}$

0.85

Agreeableness (A)

Trust/Compliance

$\begin{array}{lll}0.23 & \mathbf{0 . 6 8} & 0.37\end{array}$

Warmth/Altruism

$0.21 \quad 0.30$

0.83

Conscientiousness (C)

Reliability/Perseverance

$0.29 \quad 0.25$

0.67 0.29

Organization/Scrupulousness

Explained variance

\begin{tabular}{lllll}
1.61 & 1.48 & 1.39 & 1.28 & 1.53 \\
\hline
\end{tabular}

Total proportion

$\begin{array}{llllll}0.16 & 0.15 & 0.14 & 0.13 & 0.15\end{array}$

Note. (SE) Emotional Stability, (E) Ascendancy, (O) Openness, (A) Agreeableness, (C) Conscientiousness. 
Table 3: TAMI-P Reliability Statistics

\begin{tabular}{lcc}
\hline Factors and Facets & $\begin{array}{c}\text { Internal Consistency } \\
(\mathrm{N}=1266)\end{array}$ & $\begin{array}{c}\text { Test-Retest } \\
(\mathrm{N}=145)\end{array}$ \\
\hline Emotional Stability (SE) & .86 & .80 \\
Serenity vs. Anxiety/Depression & .86 & .81 \\
Self-Control vs. Anger/Impulsiveness & .75 & .71 \\
Ascendancy (E) & .84 & .88 \\
Leadership & .80 & .86 \\
Competitive Spirit & .84 & .87 \\
Openness (O) & .81 & .86 \\
Change/Imagination & .70 & .70 \\
Intellect & .87 & .86 \\
Agreeableness (A) & .84 & .84 \\
Trust/Compliance & .78 & .83 \\
Warmth/Altruism & .84 & .76 \\
Conscientiousness (C) & .86 & .84 \\
Reliability/Perseverance & .72 & .66 \\
Organization/Scrupulousness & .88 & .86 \\
\hline
\end{tabular}


Structural \& Psychometric Properties of TAMI-P 31

Table 4: Inter Factor Correlation Matrix

\begin{tabular}{lcccc}
\hline FACTORS & SE & E & O & A \\
\hline Emotional Stability (SE) &. & & & \\
Ascendancy (E) & .24 &. & & \\
Openness (O) & .29 & .31 &. & .33 \\
Agreeableness (A) & .41 & .29 & .33 & .34 \\
Conscientiousness (C) & .38 & .35 & .28 &
\end{tabular}

Note. $N=1,266$. All correlations are statistically significant, $p<0.05$. 
Table 5: Correlation matrix of TAMI-P, BFQ AND NEO PI-R factors

\begin{tabular}{|c|c|c|c|c|c|c|c|c|c|c|c|}
\hline & \multicolumn{5}{|c|}{$\begin{array}{c}\text { BFQ } \\
N=681\end{array}$} & \multicolumn{5}{|c|}{$\begin{array}{l}\text { NEO PI-R } \\
N=128\end{array}$} \\
\hline & & SE & $\mathrm{E}$ & $\mathrm{O}$ & A & $\mathrm{C}$ & SE & $\mathrm{E}$ & $\mathrm{O}$ & A & $\mathrm{C}$ \\
\hline \multirow{5}{*}{$\sum_{i}^{\stackrel{1}{\xi}}$} & $\mathrm{SE}$ & .68 & .32 & .25 & .32 & .33 & .77 & .25 & $.13^{\mathrm{ns}}$ & .32 & .28 \\
\hline & E & .18 & .62 & .28 & .12 & .36 & $.24^{\mathrm{ns}}$ & .47 & $.09^{\mathrm{ns}}$ & $.26^{\mathrm{ns}}$ & $.31^{\mathrm{ns}}$ \\
\hline & $\mathrm{O}$ & .20 & .31 & .60 & .35 & .30 & .22 & .20 & .80 & $.06^{\mathrm{ns}}$ & $.04^{\mathrm{ns}}$ \\
\hline & A & .27 & .32 & .24 & .53 & .18 & .29 & .49 & .31 & .71 & $.06^{\mathrm{ns}}$ \\
\hline & $\mathrm{C}$ & .29 & $.29^{\mathrm{ns}}$ & .20 & .22 & .62 & .27 & $.08^{\mathrm{ns}}$ & .18 & $.10^{\mathrm{ns}}$ & .84 \\
\hline
\end{tabular}

Note. Unless denoted by $n s$, all correlations are statistically significant, $p<0.05$. 
Table 6: Correlation matrix ${ }^{\mathrm{a}}$ of TAMI-P and NEO PI-R facets

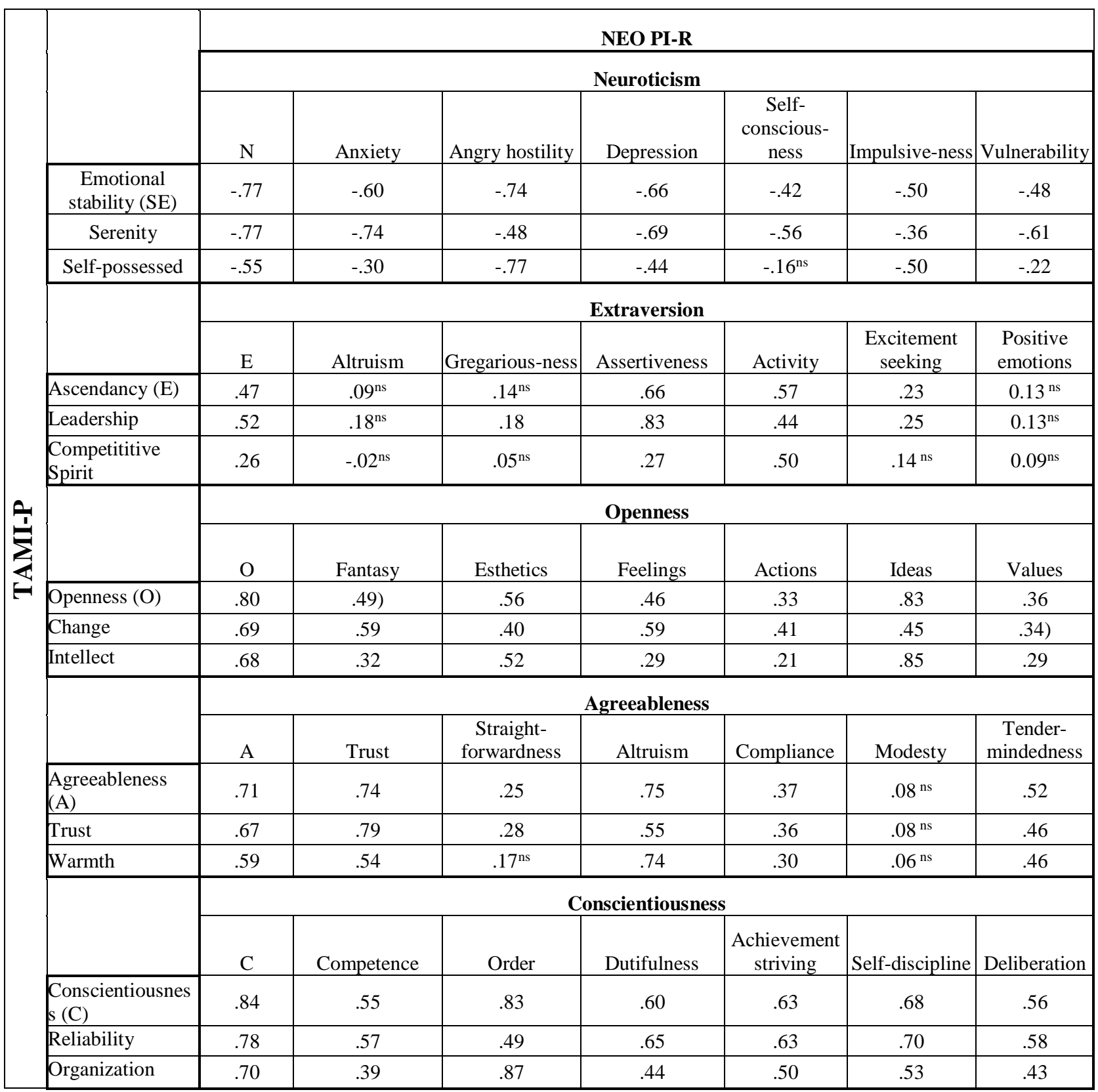

Note. Unless denoted by $n s$, all correlations are statistically significant, $p<0.05$. 